\title{
KAJIAN PUSTAKA: PEMICU KANKER DALAM SATE, AYAM/BEBEK/IKAN BAKAR/GORENG DAN ABON
}

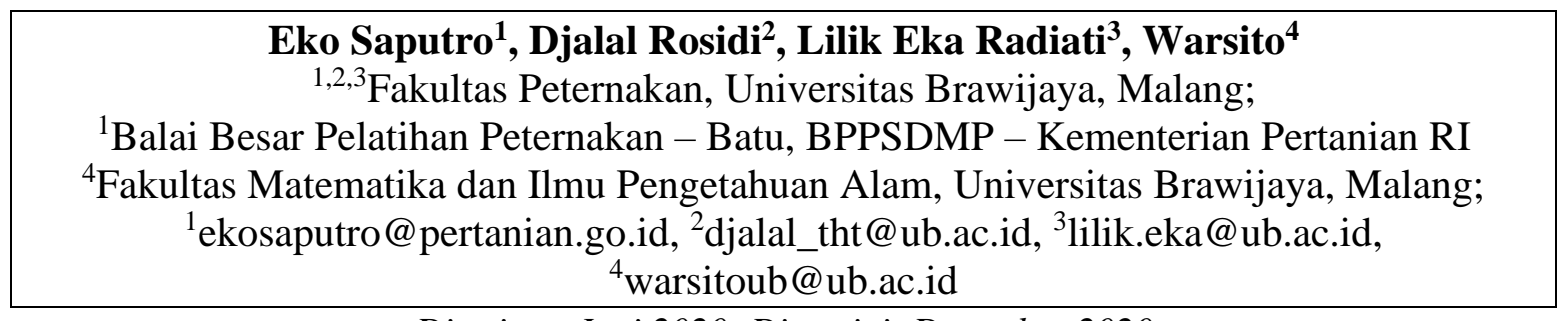

Diterima: Juni 2020; Disetujui: Desember 2020

\begin{abstract}
Indonesian people are very fond of consuming satay, grilled/fried chicken/duck/ fish because these are very delicious but consumers still do not understand that there are carcinogenic consequences of heterocyclic aromatic mines (HAA) and polycyclic aromatic hydrocarbons (PAH) which are harmful to health. This paper aims to explore HAA, PAH and various ways that have succeeded in minimizing these levels so that consumers can still enjoy these foods safely and comfortably. This paper was compiled based on a systematic literature review; the authors conducted a content analysis on 41 peer-reviewed journal articles. Thermal meat processing is an important process to ensure microbiological safety, eliminate antinutrical factors, improving digestibility and bioavailability of nutrients and develop the profile of the color, aroma and flavor attributes that we want. However, this process also turns out to bring about carcinogens (cancer triggers), HAA and PAH that are potentially harmful to our health in the long run. Their formation is highly dependent on various factors such as cooking method, cooking time, cooking temperature, type of meat, fat contents, moisture contents, $\mathrm{pH}$ and creatinine contents of meat. Many studies conclude that HAAs and PAHs are responsible for causing cancers in humans and animals. The results of this literature review provide practical information that can be applied by producers or housewives to minimize HAAs levels in finished products, which is choosing the right sugar for marination; addition of synthetic antioxidants; addition of natural antioxidants; addition of phytochemical and herbal extracts; and pretreatment using a microwave.
\end{abstract}

Keyword: heterocyclic amines, polycyclic aromatic hydrocarbons, carcinogen, meat, cancer.

Abstraksi. Masyarakat Indonesia sangat gemar mengonsumsi sate, ayam/ bebek/ ikan bakar atau goreng karena sangat nikmat tetapi konsumen masih belum mengerti bahwa ada konsekuensi karsinogen heterocyclic aromatic amines (HAA) dan polycyclic aromatic hydrocarbons (PAH) yang berbahaya bagi kesehatan. Makalah ini bertujuan untuk mengupas tuntas HAA, PAH dan berbagai cara yang telah berhasil meminimalkan kadar mereka agar konsumen tetap dapat menikmati pangan tersebut dengan aman dan nyaman. Makalah ini disusun berdasarkan tinjauan literatur yang sistematis, penulis melakukan analisis konten pada 41 artikel jurnal peer-review. Pemanasan daging adalah proses wajib untuk memastikan keamanan mikrobiologis, menghilangkan faktor antinutrisional, meningkatkan kecernaan dan bioavailabilitas nutrien, serta mengembangkan profil atribut warna, aroma dan citarasa daging yang kita inginkan. Namun, proses ini juga ternyata memunculkan karsinogen (pemicu kanker) HAA dan PAH yang berbahaya bagi kesehatan kita dalam jangka panjang. Pembentukkan HAA dan PAH sangat tergantung pada berbagai faktor seperti metode pemanasan, waktu pemanasan, suhu pemanasan, jenis daging, kadar lemak, kadar air, pH dan kadar kreatinin daging. Banyak penelitian menyimpulkan bahwa HAA dan PAH menyebabkan kanker pada manusia dan hewan. 
Hasil telaah pustaka ini memberikan informasi praktis yang bisa diterapkan oleh para produsen atau ibu rumah tangga untuk meminimalkan kadar HAA pada produk jadi, yakni memilih gula yang tepat untuk marinasi; penambahan antioksidan sintetis; penambahan antioksidan alami; dan praperlakuan menggunakan microwave.

Kata kunci: heterocyclic aromatic amines, polycyclic aromatic hydrocarbons, karsinogen, daging, kanker.

\section{PENDAHULUAN}

Masyarakat Indonesia sangat gemar mengonsumsi olahan daging/ikan panggang/bakar/goreng karena sangat nikmat. Pangan tradisional Indonesia yang berbasis daging yang dipanggang seperti sate telah menjadi makanan nasional Indonesia. Setiap tamu negara, wajib disuguhi sate. Pangan olahan daging lainnya yang dipanggang/ dibakar/ digoreng, seperti iga/ ayam/ bebek bakar/ goreng, steak, kebab, burger, sosis/ bakso bakar dan abon juga tidak kalah nikmat sehingga juga digemari konsumen. Di balik kenikmatannya, konsumen lengah dan masih banyak yang belum mengerti bahwa ada konsekuensi karsinogen heterocyclic aromatic amines (HAA) dan polycyclic aromatic hydrocarbons (PAH) yang berbahaya bagi kesehatan.

Pemanasan daging adalah proses penting untuk memastikan keamanan mikrobiologis, menghilangkan faktor antinutrisional dan mengembangkan profil atribut warna, aroma dan cita rasa daging yang kita inginkan. Namun, proses ini juga ternyata memunculkan HAA, PAH dan produk sampingan lainnya yang berpotensi berbahaya bagi kesehatan kita dalam jangka panjang. Skog et al. (2000) telah melaporkan bahwa kondisi pemanasan yang drastis seperti pemanggangan (grilling dan roasting) dapat menyebabkan kandungan HAA lebih tinggi secara signifikan. Prekursor untuk kelompok senyawa aromatik polisiklik tersebut adalah komponen pangan yang fundamental yaitu gula, asam amino dan kreatin, yang mengalami reaksi Maillard membentuk HAA. Lebih dari dua lusin HAA telah diidentifikasi dalam pangan yang diolah dengan pemanasan. Wang et al. (2019) melaporkan bahwa dari beberapa jenis HAA telah diklasifikasikan sebagai karsinogen yang potensial bagi manusia oleh IARC (International Agency for Research on Cancer - WHO). HAA sangat signifikan berisiko bagi kesehatan mengingat fakta bahwa keberadaan HAA di kebanyakan komponen pangan kita yang paling penting.

Mengenai PAH yang merupakan kelas terbesar karsinogen kimiawi yang telah dikenal terlibat sebagai agen penyebab kanker payudara, paru-paru dan usus besar dan telah dikaitkan dengan imunosupresi, teratogenisitas, toksisitas saraf, reproduksi dan perkembangan serta toksisitas akut atau kronis pada jaringan lain seperti tulang dan mukosa usus (Ramesh et al., 2004).

PAH secara terus-menerus akan diproduksi dan dilepaskan ke atmosfer dari alam dan sebagian besar dari sumber antropogenik. PAH terutama dibentuk oleh pembakaran tidak sempurna atau pirolisis bahan organik (pembakaran yang tidak sempurna pada batu bara, minyak, gas, kayu, sampah atau zat organik lainnya) selama berbagai proses industri dan proses geokimia (kebakaran hutan dan aktivitas vulkanik) (EFSA, 2008). PAH terjadi dalam jumlah yang cukup besar di lingkungan (udara, air, tanah) dan makanan (Wenzl et al., 2006). Karena PAH adalah kontaminan lingkungan yang ada di mana-mana, 
sehingga manusia tak terhindarkan terkena paparannya. Dalam populasi tanpa asap rokok/ tembakau dan populasi yang terpapar selain dalam pekerjaan, diet dapat berkontribusi lebih dari $70 \%$ dari total paparan PAH (Komisi Eropa, 2002; Martorell et al., 2010). Ada berbagai sumber paparan PAH pada manusia, sehingga membuatnya sulit untuk menilai kontribusi terhadap PAH karena asupan makanan.

Makalah ini membahas tentang struktur kimia, proses terbentuknya dan beberapa strategi mitigasi terbentuknya HAA dan PAH. Dengan demikian diharapkan konsumen tetap dapat menikmati olahan pangan tersebut dengan aman dan nyaman. Makalah ini disusun berdasarkan tinjauan literatur yang sistematis, penulis melakukan analisis konten pada 41 artikel jurnal peerreview.

\section{METODE PENELITIAN}

Kami melakukan tinjauan literatur yang sistematis karena pendekatan ini menawarkan untuk dapat menganalisis secara mendalam semua artikel yang relevan tentang topik ini, dan juga memiliki potensi untuk mendeteksi konsep lain yang belum tereksplorasi. Database Library Genesis dan Google Scholar digunakan sebagai sumber data. Library Genesis adalah basis data paling komprehensif dan open acces semua jurnal peer-review terindeks Scopus dan diterbitkan di Science Direct dan Google Scholar adalah salah satu basis data terbesar yang tersedia. Untuk pencarian awal, kami menggunakan istilah pencarian dan kata kunci berikut secara mandiri atau digabungkan menggunakan kata "AND" dan "OR": "heterocyclic aromatic amines (HAA)", "polycyclic aromatic hydrocarbons (PAH)", "carcinogen", "meat/ beef/ chicken" dan "cancer".

Kami hanya memilih artikel yang ditulis dengan Bahasa Inggris yang diterbitkan sejak tahun 2000 dan seterusnya. Selain itu, artikel-artikel tersebut harus dipublikasikan di jurnal peer-reviewed yang memiliki impact factor karena dianggap memberikan data yang valid dan memiliki paling banyak pengaruh di lapangan. Langkah pertama dari analisis artikel adalah pemeriksaan untuk data yang berlebihan dan abstrak ditinjau berdasarkan kriteria inklusi. Kriteria inklusi tersebut meliputi HAA dan PAH yang terjadi pada olahan daging dan ikan yang diolah dengan cara dipanaskan (dipanggang/dibakar dan digoreng). Kriteria eksklusi meliputi HAA dan PAH yang terjadi pada asap pembakaran rokok, cerobong asap pabrik dan asap kendaraan. Jika abstrak dari artikel masih relevan atau memenuhi kriteria inklusi tersebut, bagian metodologi dan pembahasan kemudian dibaca dan dirangkum.

Kami awalnya mengidentifikasi total 172 artikel (Google Scholar: 100 dan Library Genesis: 72 artikel). Selanjutnya, pada langkah ke-2 kami mengurangi 35 artikel karena redundansi antar berbagai mesin pencari. Pada Langkah 3, abstrak dari 137 artikel yang tersisa diperiksa dengan kriteria inklusi, menghasilkan 54 artikel tersisa. Bagian pendahuluan, metodologi dan pembahasan dari artikel-artikel tersebut diperiksa secara terperinci dengan kriteria inklusi (Langkah 4). Filter akhir ini meninggalkan 41 artikel yang sepenuhnya memenuhi kriteria inklusi yang selanjutnya kami gunakan dalam makalah tinjauan pustaka ini.

\section{HASIL DAN PEMBAHASAN \\ Heterocyclic Aromatic Amines (HAA)}




\section{Penelitian HAA Terdahulu}

Pada tahun 1977 telah ditemukan sejumlah besar mutagen dalam partikel asap dari pemanasan/ pemasakan bahan makanan kaya protein (Sugimura et al., 1977b Fakta yang menunjukkan bahwa asap kondensat dari rokok mengandung mutagen dan karsinogen telah menginspirasi dan menjadi dasar pemikiran penelitian awal tentang HAA. Selanjutnya inspirasi tersebut berlanjut pada penemuan aktivitas mutagenik yang ditampilkan pada bagian yang hangus ikan dan daging goreng (Sugimura et al., 1977b; Nagao et al., 1977b serta dalam protein dan asam amino pirolisis (Nagao et al., 1977a; Ko-suge et al., 1978 Mutasi tersebut ditemukan karena senyawasenyawa dasar dalam bahan-bahan tersebut. Melalui beberapa langkah purifikasi, lebih dari 20 HAA telah diisolasi dan struktur dari 19 di antaranya telah dilaporkan (Sugimura, 1986, 1992; Wakabayashi et al., 1992 Yahagi et al. (1977) meneliti senyawa HAA menggunakan metode Ames' Salmonella typhimurium TA98 dan campuran S9 dari hati tikus yang disuntik dengan polychlorinated biphenyls dan memodifikasi metode tersebut dengan preinkubasi. Hanya satu dari semua yang ditemukan menjadi senyawa baru dan 10 di antaranya telah terbukti sebagai karsinogenik melalui penelitian jangka panjang pada hewan pengerat (Esumi et al., 1989; Ito et al., 1991; Ohgaki et al., 1991; Takahashi et al., 1993; Tamano et al., 1994).

Menurut Sugimura (1997) penemuan yang menarik tersebut telah berdampak besar dan menjadi pusat perhatian bagi komunitas ilmiah. Alasannya pertama karena HAA diisolasi dari makanan yang dimasak dalam kondisi normal. Alasan kedua, kebanyakan HAA yang ditemukan sangat mutagenik bagi $S$. typhimurium
TA98 dan mampu menginduksi neoplasma pada hewan pengerat. Terakhir, alasannyaa karena manusia ternyata terus-menerus terpapar HAA. Hal ini mengakibatkan sampai saat ini, makalah ilmiah terkait HAA telah terbit secara terus-menerus, dengan banyak lompatan dramatis.

Widmark's adalah perintis penelitian terkait HAA yang pertama kali pada tahun 1939 di Universitas Lund. Mereka menemukan bahwa ekstrak pelarut organik daging kuda panggang telah mengakibatkan pembentukan tumor kelenjar susu pada tikus (Widmark, 1939).

Baru di tahun 1975 - 1977 dimulai langkah awal yang nyata penelitian tentang HAA oleh Pusat Kanker Nasional, Tokyo. Mereka menemukan agen mutagenik dalam asap dari pemanasan ikan dan daging. Temuan ini pertama kali dipresentasikan dalam lokakarya Mutagenesis dan Karsinogenesis Lingkungan kerjasama Program Ilmu Medis AS - Jepang di Seattle pada tahun 1975. Selanjutnya mereka kembali mempresentasikan hasil temuan tersebut ke khalayak yang lebih luas pada Simposium Masyarakat Kanker Kanada, yang diadakan bersama dengan Asosiasi Penelitian Kanker Amerika di Toronto pada tahun 1976 dan Simposium tentang Asalusul Kanker pada Manusia yang diadakan di Cold Spring Harbor pada tahun 1976 (Sugimura et al., 1977b). Setahun setelahnya, Commoner et al. (1978)) melaporkan mutagenisitas dari konstituen daging yang dimasak. Protein menjadi sumber mutagenisitas pada ikan dan daging yang dimasak. Oleh karena itu, produk yang dipanaskan dari asam amino individu diteliti secara intensif berkolaborasi dengan Kosuge dan rekan, dari Shizuoka College of Pharmacy, serta shudo dan tim dari Universitas Tokyo. Hasilnya, 3-amino-1,4dimethyl-5 $\mathrm{H}$-pyrido[4,3- b]indole (Trp- $\mathrm{P}$ - 
1) dan 3-amino-1-metil- $5 \mathrm{H}$-pyrido[4,3-b] indole (Trp-P-2) berhasil diisolasi dan diidentifikasi sebagai mutagen dalam pirolisis triptofan (Sugimura et al., 1977a). Sedangkan 2-amino-6-methyldi- pyrido [1,2- $\alpha: 3$ ' ,2' - d] imidazole ( Glu-P-1) dan 2- aminodipyridow1,2- $\alpha: 3$, , 2' - d] imidazole (Glu-P-2) ditemukan sebagai produk pirolisis mutagenik dari asam glutamat (Yamamoto et al., 1978). Pada saat yang sama, sebuah kelompok di Japan Tobacco and Salt Public Corporation yang meneliti mutagenisitas dalam kondensat asap rokok, mengidentifikasi 2-amino-9 $\mathrm{H}$ pirido[2 , 3- b]indole $(\mathrm{A} \alpha \mathrm{C})$ dan 2-amino-3metyl- 9 H-pirido[2,3- b]indole $(\mathrm{MeA} \alpha \mathrm{C})$ sebagai mutagen dari kacang kedelai globulin pirolisis (Yoshida et al., 1978).

Kelompok riset di National Cancer Centre, Tokyo juga meluncurkan penelitian tentang isolasi serta penentuan struktur mutagen pada daging dan ikan masak. Kegiatan tersebut dalam waktu yang tidak lama telah berhasil mengidentifikasi 2amino-3-methyl imidazo [4,5- f] quinoline (IQ) dan 2-amino-3,4-dimethylimidazo [4,5f] quinoline (MeIQ) dari ikan sarden keringmatahari yang dipanggang (Kasai et al., 1980a, b). Setelah itu, juga berhasil diidentifikasi 2-amino-3,8-dimethylimidazo [4,5- $\mathrm{f}$ ]quino-xaline (MeIQx) dalam daging sapi goreng (Kasai et al., 1981). Pada Laboratorium Nasional Lawrence Livermore pada tahun 1986, Felton dan tim juga berhasil mengisolasi 2-amino-1-metil6-phenylimidazo[4,5b] piridin (PhIP) dalam daging sapi goreng (Felton dan Knize ,1990).

Menurut struktur kimianya, HAA dapat dibagi menjadi dua kategori, yaitu aminokarbolin (amino-carboline) dan aminoimidazole - azaarene (amino imidazole - azaarene) (Skog et al., 1998). Amino-karbolin umumnya terbentuk pada suhu yang jauh lebih tinggi $\left(>300{ }^{\circ} \mathrm{C}\right.$ ) melalui pirolisis asam amino atau protein sehingga sering disebut HAA pirolitik atau HAA tipe non-IQ. Pembentukan aminoimidazole-azaarene terbentuk pada suhu yang lebih rendah. HAA juga dapat diklasifikasikan berdasarkan polaritasnya. Sejauh ini, HAA penting yang telah menunjukkan aktivitas karsinogenik dalam percobaan pada tikus dan/ atau telah dikaitkan dengan peningkatan risiko kesehatan dalam penelitian epideomiologis adalah yang terkait pada kelompok polar (Shan et al, 2004; Archer et al ., 2000; Tang et al., 2007; Shin et al., 2002). HAA telah diklasifikasikan ke dalam dua kelompok. Kelompok pertama, HAA yang dihasilkan oleh pirolisis asam amino dan protein melalui reaksi radikal, yaitu Trp-P-1, Trp-P2, Glu-P-1, Glu-P-2, A $\alpha \mathrm{C}$ dan MeA $\alpha \mathrm{C}$. Kelompok kedua, HAA dihasilkan akibat pemanasan campuran kreatin (in), gula dan asam amino yakni IQ, MeIQ, MeIQx dan PhIP seperti yang dilaporkan oleh Jagerstad et al., (1991). Kelompok pertama HAA atau disebut kelompok pirolitik atau HAA tipe non-IQ, seperti Trp-P-1 dapat diinaktifkan oleh konversi sebuah gugus amino eksosiklik menjadi gugus hidroksi dengan diencerkan nitrit $(2 \mathrm{mM})$. Hal ini tidak terjadi pada kelompok kedua HAA atau disebut kelompok termik atau HAA tipe IQ. Kelompok pertama HAA dominan hadir dalam kondensat asap rokok, sedangkan kelompok kedua HAA dominan hadir dalam daging yang masak (Tsuda et al., 1985).

\section{Mekanisme Terbentuknya HAA}

Pais et al (1999) telah melaporkan bahwa HAA adalah produk sampingan yang berbahaya dari perlakuan panas pada produk hewani. Pembentukan HAA dipengaruhi baik oleh faktor intrinsik atau faktor ekstrinsik. Faktor intrinsik terkait senyawa 
alami yang terkandung dalam daging dan merupakan faktor pembentuk yang utama yakni kadar dan jenis dari asam amino dan gula serta karakteristik matriks pangan (yang dapat mempengaruhi interaksi antar prekursor). Faktor ekstrinsik terkait dengan perlakuan atau metode pengolahan daging yakni kondisi pemanasan (misalnya: suhu, waktu, penggunaan bara api secara langsung, dll) dan metode penyiapan pangan sebelum pemanasan (misalnya: jenis marinasi, bahan tambahan, dll). Oleh karena itu, bahan pangan yang sama dapat memiliki kadar dan profil HAA yang berbeda setelah perlakuan panas yang berbeda.

Jagerstad et al. (1998) melaporkan bahwa HAA kategori amino-karbolin atau kelompok HAA pirolitik adalah produk pirolitik dan kreatin tidak diperlukan dalam pembentukannya. Oleh karenanya aminokarbolin dapat terbentuk dalam pangan nabati meskipun pangan hewani adalah sumber utamanya. Skog et al., (1998) melaporkan bahwa generasi radikal bebas yang diinduksi oleh panas dan generasi subsekuen dari fragmen reaktif seperti pyridine dan pyrazine telah ditemukan menjadi mekanisme utama yang terlibat dalam pembentukan amino-karbolin. Kondensasi fragmen reaktif dan penyusunannya ulang tersebut memunculkan berbagai struktur baru.

Weisburger (2005) melaporkan bahwa berbeda dengan amino-karbolin, kreatin (kreatinin / hasil metabolism kreatin) telah diidentifikasi menjadi sebuah komponen penting dalam jalur pembentukan HAA kategori amino-imidazole-azaarene atau HAA kelompok termik. Sejatinya adalah kreatinin, hasil dari reduksi kreatin, yang berkontribusi pada pembentukan aminoimidazole-azaarene yaitu IQ, IQx, dan PhlP. Kreatinin adalah sebuah produk turunan alami fosfat kreatin. Jumlah kreatinin dalam otot sangat rendah. Menariknya, penambahan kreatinin ekstra ke permukaan daging sebelum penggorengan ternyata meningkatkan kadar HAA. Selama pemanasan, kreatin dapat dikonversi menjadi kreatinin melalui siklisasi dan eliminasi air. Sementara itu, senyawa perantara seperti piridin dan pirazin serta karbonil reaktif dapat terbentuk dari reaksi Maillard antara asam amino dan gula pereduksi serta reaksi degradasi Strecker. Jagerstad et al. (1998) melaporkan bahwa kreatinin membentuk bagian amino-imidazo yang bergabung dengan fragmen reaktif di atas melalui kondensasi aldol, sehingga memunculkan aminoimidazole-azaarene yang lain. Suhu pemanasan yang relatif lebih rendah $\left(<300^{\circ} \mathrm{C}\right)$ yang cukup untuk menggerakkan reaksi Maillard dan degradasi Strecker untuk menghasilkan fragmen reaktif dari prekursor (gula, asam amino, dan turunannya) (Skog et al., 2000). Secara umum, kandungan HAA dalam bahan pangan dan model kimia meningkat seiring dengan suhu dan waktu pemanasan (Jagerstad et al., 1998; Skog et al., 1997). Juga telah diamati bahwa kandungan HAA berkorelasi dengan warna permukaan daging, semakin gelap warnanya, semakin tinggi konsentrasi HAA (Aaslyng et al., 2013). Beberapa penelitian juga melaporkan bahwa radikal, terutama radikal piridin dan pirazin, juga terlibat dalam pembentukan aminoimidazole-azaarene (Milic et al., 1993 Meskipun demikian, temuan dari penelitian terkini menunjukkan bahwa jalur yang dimediasi radikal bebas adalah bukan mekanisme utama terbentuknya aminoimidazole-azaarene (Cheng et al., 2009; Zhang et al ., 2015). 
Strategi Mitigasi Meminimalkan Kadar HAA

\section{Memilih Gula yang Tepat untuk Marinasi}

Telah diketahui bahwa gula, terutama gula pereduksi, adalah prekursor utama terbentuknya HAA. Oleh karena itu, perubahan kandungan dan jenis gula dapat mempengaruhi secara signifikan pembentukan HAA dalam pangan. Selain itu, efek yang ditimbulkannya dapat sangat berbeda pada suhu pemanasan yang berbeda. Pemanasan pangan pada rentang suhu yang lebih rendah $\left(\sim 100{ }^{\circ} \mathrm{C}\right)$ dengan diikuti penambahan jumlah gula pereduksi dapat mendukung pembentukan HAA (Lan dan Chen, 2002). Sebaliknya, penambahan gula pereduksi di luar kisaran konsentrasi tertentu dapat menurunkan pembentukan HAA dalam daging sapi giling dan patties daging sapi yang dipanaskan antara 150 dan $200{ }^{\circ} \mathrm{C}$ (Kikugawa et al., 2000). Madu terkadang digunakan sebagai pengganti gula untuk menambahkan rasa manis saat marinasi. Sebuah penelitian (Hasnol et al., 2014) yang mengevaluasi efek dari berbagai jenis gula pada pembentukan HAA dalam ayam bakar menemukan bahwa marinasi dengan madu menyebabkan penurunan kadar HAA dalam sampel dada ayam bakar dibandingkan dengan yang dimarinasi dengan gula merah atau gula pasir. Namun, penulis tidak memverifikasi lebih lanjut apakah efek penghambatan yang teramati disebabkan oleh gula dalam madu atau hal ini adalah sebuah efek terintegerasi dari gula dan komponen lainnya.

Studi yang dilakukan oleh Shin dan Utsunol (2004) melaporkan penurunan HAA total sebanyak $24 \mathrm{ng} / \mathrm{g}$ (MeIQx, DiMeIQx, dan PhIP) dalam ayam goreng yang dimarinasi dengan bahan-bahan campuran, terdiri dari jus lemon, kecap, bawang putih cincang, semanggi, dan madu.
Salmon et al. (1997 dalam Wang et al., 2019) melaporkan penurunan 92-99\% PhIP dalam ayam panggang utuh yang direndam dengan campuran gula merah, minyak zaitun, cuka, bawang putih, mustard, jus lemon, dan garam.

\section{Penambahan Antioksidan Sintetis}

Pengetahuan tentang mekanisme pembentukan HAA telah memfasilitasi pengembangan banyak metode penghambatan HAA. Radikal bebas dan senyawa antara reaktif lainnya terutama karbonil telah ditunjukkan menjadi partisipan kunci pembentukan HAA. Sesuai dengan dasar mekanistik ini, antioksidan telah menjadi kelompok calon inhibitor HAA yang paling penting. Dalam percobaan pembuktian konsep awal, para peneliti menguji efek dari beberapa antioksidan sintetik yang umum seperti butylated hydroxyanisole (BHA), butylated hydroxytoluene (BHT), propyl gallate (PG), dan tert-butylhydroquinone (TBHQ). Menariknya, efeknya ternyata sangat tergantung pada sistem eksperimental yang digunakan. Dalam sistem pangan, antioksidan ini mampu menghambat pembentukan HAA bahkan dengan penambahan pada tingkat yang rendah (Chen, 1988 dalam Wang et al., 2019; Lan et al., 2004). Dalam model kimia yang mengandung prekursor HAA murni, BHT dan TBHQ ditemukan dapat mempromosikan terbentuknya HAA. Efeknya sangat kuat dengan TBHQ dapat meningkatkan pembentukan HAA jenis MeIQx >200\% (Johansson dan Jagerstad, 1996). Terlepas dari temuan yang tidak konsisten pada aktivitas antioksidan sintetik terhadap pembentukan HAA, studi-studi pembuktian konsep ini setidaknya menambah kekuatan bukti bahwa antioksidan dapat menjadi penghambat 
mekanisme terbentuknya HAA yang penting dalam keadaan tertentu.

\section{Penambahan Antioksidan Alami}

Agen alami umumnya lebih disukai daripada yang sintetis sebagai bagian komposisi makanan atau bahan tambahan pangan. Ada banyak antioksidan alami yaitu vitamin, fenolik, dan karotenoid telah dievaluasi efeknya terhadap pembentukan HAA. Mirip dengan antioksidan sintetik yang disebutkan di atas, vitamin seperti vitamin $\mathrm{C}$ dan $\alpha$-tokoferol menunjukkan kegagalan dalam efek yang konsisten untuk pembentukan HAA (Kikugawa et al., 2000), meskipun mereka memiliki kemampuan untuk mengganggu jalur reaksi yang dimediasi radikal bebas (Shin, 2005). Faktanya, polifenol alami adalah kelompok besar fitokimia dengan rentang antioksidan yang luas atau kapasitas penyergapan radikal bebas yang kuat. Sejauh ini, laporan tentang efektivitas relatif dari polifenol alami sebagai inhibitor pembentukan HAA adalah lebih konsisten dibandingkan dengan yang antioksidan sintetis dan vitamin. Mereka dapat ditambahkan dalam bentuk fitokimia murni yang diisolasi dari tanaman atau dalam bentuk ekstrak yang kaya polifenol. Buah-buahan, sayuran, atau rempah-rempah banyak mengandung polifenl alami. Kita dapat mencampurkannya ke dalam masakan kita sehari-hari.

Senyawa Intermediet Maillard tertentu, terutama spesies karbonil reaktif (reactive carbonyl species/ RCS) yang dihasilkan dari pemanasan dan/ atau reaksi degradasi Strecker menjadi senyawa perantara yang menjadi kunci dalam pembentukan HAA (Jagerstad et al., 1998; Persson et al., 2003; Cheng et al., 2006). Kelompok mereka adalah yang pertama melaporkan penyergapan karbonil reaktif sebagai mekanisme utama yang bertanggung jawab atas efek penghambatan polifenol alami tertentu (Cheng et al., 2008). Dengan demikian, inhibitor polifenol yang ditambahkan digabungkan dengan senyawa inter-mediate HAA reaktif membentuk senyawa tambahan baru (adduct). PhIP adalah jenis HAA yang paling banyak diteliti terkait dengan mekanisme aksi postulat ini dan senyawa intermediate karbonil reaktif utama yang terlibat adalah fenil asetaldehid. Sebuah penelitian terkini lebih jauh menegaskan pentingnya mekanisme ini dalam aktivitas penghambatan polifenol terhadap pembentukan HAA (Zhu et al., 2016). Para penulis menunjukkan korelasi positif yang signifikan antara kapasitas penyergapan oleh phenylacetaldehyde dan aktivitas penghambatan pembentukan PhIP dari sekelompok polifenol dengan beragam kapasitas antioksidan.

\section{Praperlakuan Microwave}

Taylor et al. (1986) mengusulkan praperlakuan microwave produk daging sebelum pemasakan dengan suhu tinggi, untuk mempersingkat waktu pemasakan, sehingga menurunkan pembentukan HAA. Felton, et al. (2000) menunjukkan bahwa dengan memberikan praperlakuan pada pastel daging sapi dengan microwave sebelum penggorengan, tingkat HAA dapat dikurangi hingga 95\%. Untuk menyelidiki suatu metode untuk mengurangi jumlah amina aromatik heterosiklik mutagenik/ karsinogenik yang terbentuk selama penggorengan daging sapi, Felton, et al. (2000) mengukur aktivitas mutagenik dalam Salmonella strain TA98 dan jumlah HAA yang diketahui melalui ekstraksi fase padat dan HPLC. Patties daging sapi diberi praperlakuan microwave dengan berbagai lama waktu sebelum penggorengan. 
Praperlakuan microwave selama $0 ; 1 ; 1,5 ; 2$; atau 3 menit sebelum penggorengan pada suhu $200^{\circ} \mathrm{C}$ atau $250^{\circ} \mathrm{C}$ selama 6 menit per sisi terbukti mampu mengurangi prekursor HAA (kreatin, kreatinin, asam amino, glukosa), air dan lemak hingga 30\%, pada patties daging sapi mengakibatkan penurunan aktivitas mutagenik HAA hingga 95\%. Jumlah dari empat amina aromatik heterosiklik yang terbukti ada, yakni MeIQx, IQ, DiMeIQx dan PhIP, menurun 3 hingga 9 kali lipat dibandingkan dengan kontrol, patties daging sapi non-microwave yang digoreng dalam kondisi yang sama.

\section{Polycyclic Aromatic Hydrocarbons (PAH)}

Pada tahun 1775, Sir Percival Pott mengamati kejadian kanker skrotum yang luar biasa tinggi dalam sapuan cerobong menghubungkan penyebabnya dengan jelaga. Kemudian, sepanjang abad ke-20, PAH diidentifikasi sebagai senyawa bahan kimia karsinogenik yang terdapat dalam jelaga, membenarkan pengamatan Pott (Šimko, 2002). Saat ini PAH merupakan kelas terbesar karsinogen kimia yang telah dikenal. PAH telah terlibat sebagai agen penyebab kanker payudara, paru-paru dan usus besar dan telah dikaitkan dengan imunosupresi, teratogenisitas, toksisitas saraf, reproduksi dan perkembangan serta toksisitas akut atau kronis pada jaringan lain seperti tulang dan mukosa usus (Ramesh et al., 2004).

PAH terus diproduksi dan dilepaskan ke atmosfer dari alam dan sebagian besar dari sumber antropogenik. PAH terutama dibentuk oleh pembakaran tidak sempurna atau pirolisis bahan organik (pembakaran yang tidak sempurna pada batu bara, minyak, gas, kayu, sampah atau zat organik lainnya), selama berbagai proses industri dan proses geokimia (kebakaran hutan, aktivitas vulkanik) (EFSA, 2008). PAH terjadi dalam jumlah yang cukup besar di lingkungan (udara, air, tanah) dan makanan (Wenzl et al., 2006). Karena PAH adalah kontaminan lingkungan yang ada di manamana, manusia tak terhindarkan terkena paparannya. Dalam populasi tanpa asap rokok/ tembakau dan populasi yang terpapar selain dalam pekerjaan, diet dapat berkontribusi lebih dari $70 \%$ dari total paparan PAH (Komisi Eropa, 2002; Martorell et al., 2010). Ada berbagai sumber paparan PAH pada manusia, sehingga membuatnya sulit untuk menilai kontribusi terhadap PAH karena asupan makanan.

\section{Klasifikasi Toksikologis}

Paparan terhadap PAH menjadi perhatian utama bagi kesehatan manusia. PAH ini beracun; beberapa jenisnya adalah karsinogenik dan non karsinogenik lainnya dapat bertindak sebagai senyawa sinergis; persisten dan bioakumulatif Karena PAH termasuk kelas terbesar bahan kimia yang dikenal sebagai karsinogen sehingga tidak mengherankan dimasukkannya PAH dalam daftar prioritas polutan oleh organisasi yang kompeten. Pada tahun 1970-an Badan Perlindungan Lingkungan (Environmental Protection Agency/ EPA) Amerika Serikat merancang 16 PAH, US-EPA PAH, sebagai senyawa yang menarik berdasarkan kemunculannya dan karsinogenisitasnya (Wenzl et al., 2006). Dalam Program Internasional tentang Keamanan Kimia (International Programme on Chemical Safety/ IPCS, 1998), 17 PAH lainnya ditambahkan pada 16 PAH yang terdaftar oleh US-EPA. Komite Ilmiah pada makanan (Scientific Committee on Food/ SCF) menyimpulkan bahwa 15 dari 33 jenis PAH yang dinilai risikonya, harus dianggap berpotensi genotoksik dan karsinogenik 
bagi manusia dan merupakan kelompok prioritas dalam penilaian risiko efek samping jangka panjang setelah asupan makanan. SCF (Komisi Eropa, 2002) menyarankan Benzo $[a]$ pyrene $(\mathrm{BaP})$ sebagai penanda terjadinya $\mathrm{PAH}$ karsinogenik dalam makanan. Namun, dalam skrining tingkat $\mathrm{PAH}$ dalam makanan (Komisi Eropa, 2005) mengamati bahwa sepertiga dari sampel yang mengandung $\mathrm{PAH}$ karsinogenik adalah negatif untuk BaP. Pendapat SCF 2002 direvisi oleh Panel EFSA (European Food Safety Authority/ Otoritas Keamanan Pangan Eropa) tentang Kontaminan dalam Rantai Makanan (Panel CONTAM). Panel CONTAM mempertahankan laporan sebelumnya $15 \mathrm{PAH}$ dan menambahkan analit ke-16 ke dalam daftar seperti yang disarankan oleh Komite Ahli Gabungan FAO/WHO tentang Aditif Makanan (Joint FAO/WHO Expert Committee on Food Additives / JEFCA, 2005). Dari daftar "15 + 1" PAH, EFSA menyimpulkan bahwa delapan PAH (PAH8): benzo[a]anthracene (BaA), chrysene

benzo $[b]$ fluoranthene (Ch), benzo $[k]$ fluoranthene (BkF), $\quad \mathrm{BaP}$, indeno[1,2,3- $c d]$ pyrene (IP), benzo $[g, h, i]$ perylene $\quad(\mathrm{BgP}), \quad \operatorname{dibenzo}[a, h]$ anthracene (DhA) - saat ini merupakan indikator yang memungkinkan untuk potensi karsinogenik dari PAH dalam makanan. Mengingat frekuensi PAH8, jumlah $\mathrm{BaA}, \mathrm{Ch}, \mathrm{BbF}$ dan $\mathrm{BaP}$ (PAH4) dapat memberikan informasi yang cukup tentang subjek ini, sehingga EFSA menyimpulkan bahwa PAH4 dan PAH8 adalah indikator PAH yang paling cocok dalam makanan (EFSA, 2008).

Tidak ada kesepakatan umum internasional pada panel PAH individu yang harus dianalisis dan daftar PAH yang dikeluarkan dari otoritas yang berbeda mungkin mengandung senyawa yang berbeda, meskipun PAH prioritas dari UE, PAH8, terdiri dari delapan PAH karsinogenik yang sama dari daftar USEPA. Dalam klasifikasi IARC (2010; 2012) yang direvisi baru-baru ini, BaP direklasifikasi sebagai karsinogen bagi manusia dan beberapa PAH lain diklasifikasikan dalam kelompok lain dari toksisitas IARC.

\section{Struktur dan Pembentukan PAH}

PAH mewakili kelas utama senyawa organik, terdiri dari ratusan senyawa, masing-masing mengandung dua atau lebih cincin aromatik yang menyatu, tanpa unsur selain karbon dan hidrogen, dalam konfigurasi linier atau sudut/ angular, (Wenzl et al., 2006; EFSA, 2008; Luch dan Baird, 2010). PAH yang mengandung dua hingga empat cincin benzena yang menyatu disebut "PAH ringan" dan PAH yang mengandung lima atau lebih cincin benzen disebut "PAH berat". PAH berat lebih stabil dan lebih beracun daripada $\mathrm{PAH}$ ringan (Wenzl et al., 2006).

Meskipun mekanisme pembentukan PAH yang tepat tidak diketahui secara pasti, pada umumnya menganggap bahwa PAH dibentuk oleh kondensasi senyawa organik yang lebih kecil oleh pirolisis atau pirosintesis. Pada suhu tinggi $\left(>400{ }^{\circ} \mathrm{C}\right.$ ), senyawa organik mudah terfragmentasi (pirolisis) dan radikal bebas menghasilkan rekombinasi untuk membentuk senyawa aromatik polinuklear yang stabil (pirosintesis). Reaksi yang umum dapat melibatkan Diels-Alder pengaturan ulang tipe untuk menghasilkan PAH. Pembentukan PAH hanya signifikan pada suhu lebih tinggi dari $400^{\circ} \mathrm{C}$ dan sebagian besar prosedur termal pada makanan berada di bawah suhu tersebut. Namun, prosedur yang melibatkan 
pembakaran yang tidak sempurna pada kayu atau arang (misalnya pengasapan, pemanggangan dan barbecuing) dengan mudah dapat mencapai suhu tinggi dan akibatnya menghasilkan PAH (Park dan Penning, 2009).

Setidaknya ada tiga mekanisme yang mungkin ada pada pembentukan $\mathrm{PAH}$ dalam daging panggang. Meskipun pembentukan PAH disukai pada suhu antara $400-1000^{\circ} \mathrm{C}$, beberapa pembentukan PAH endogen pada permukaan makanan juga dapat terjadi melalui pirolisis bahan organik seperti kolesterol, trygliserida, protein dan karbohidrat pada suhu di atas $200^{\circ}$ C. Mekanisme lain, terutama yang relevan dalam makanan yang diasap adalah kontaminasi dari asap yang ditimbulkan oleh pembakaran sumber panas yang tidak sempurna yang dapat menghasilkan $\mathrm{PAH}$ yang dibawa ke dalam permukaan makanan. Telah dikemukakan bahwa PAH dengan berat molekul rendah (mengandung 2-3 cincin aromatik) timbul dari asap yang dihasilkan selama pemanggangan daging karena PAH ini lebih mudah menguap daripada PAH dengan berat molekul tinggi (mengandung lebih dari 3 cincin aromatik) (Ferrarese et al., 2008; Park and Penning, 2009). Mekanisme ketiga, yang bertanggung jawab pada konsentrasi PAH yang lebih besar telah terbukti muncul dari pirolisis lemak. Ketika lemak meleleh menetes pada sumber panas yang intens menghasilkan senyawa-senyawa tersebut terbawa kembali ke permukaan makanan (Farhadian et al., 2010) dan lemak juga menyebabkan flashing (kilatan) yang meningkatkan suhu di dekat makanan (Sinha et al., 1995). Kandungan lemak merupakan faktor penting yang mempengaruhi tingkat $\mathrm{PAH}$ dalam makanan berbasis daging (EFSA, 2008; Farhadian et al., 2010).

\section{Kejadian PAH dalam Makanan yang Dimasak}

PAH terjadi sebagai kontaminan dalam berbagai kategori makanan, air minum dan minuman. PAH bisa masuk dalam rantai makanan dengan cara yang berbeda: kontaminasi lingkungan, melalui udara (pengendapan secara langsung dari atmosfer), tanah (dengan perpindahan) dan/ atau air (pengendapan dan perpindahan), misalnya buah-buahan, sayuran dan makanan laut; kontaminasi dari bahan kemasan; dan kontaminasi PAH (dari asap kayu) dan/ atau pembentukan PAH (dari komponen makanan) selama pemprosesan termal makanan yang terjadi dalam proses persiapan dan pembuatan makanan (pengeringan dan pengasapan) dan pemasakan (roasting, baking, grilling and frying) (EFSA, 2008; Plaza-Bolaños et al., 2010).

Konsentrasi $\mathrm{PAH}$ tertinggi biasanya ditemukan dalam makanan yang dibakar dengan arang (seperti produk daging berlemak dan daging yang dipanggang dalam kondisi berkepanjangan dan parah) dan memberikan kontribusi signifikan terhadap asupan PAH jika makanan tersebut merupakan bagian besar dari diet yang biasanya (EFSA, 2008). Dengan metode memasak selain dipanggang, jumlah PAH yang diproduksi biasanya rendah. Kadar PAH umumnya yang diproduksi dalam makanan berbasis daging yang dibakar meningkat dengan meningkatnya kadar lemak (tergantung jenis makanan), kedekatan dengan sumber panas dan waktu yang lebih lama untuk mencapai kematangan yang dibutuhkan. Sumber panas dan geometri juga penting, panggangan kayu dan arang dapat menimbulkan lebih banyak PAH daripada oven atau panggangan listrik, dan 
pemanggang vertikal membentuk tingkat $\mathrm{PAH}$ yang sangat rendah dibandingkan dengan peralatan horisontal (EFSA, 2008).

Kazerouni et al. (2001) menginvesti-gasi 200 item makanan untuk $\mathrm{BaP}$ dan menemukan bahwa daging yang dipanggang dengan kematangan well dan well-done menunjukkan konsentrasi tertinggi, menghasilkan nilai sekitar 5 ng/g. Batas maksimum kadar $\mathrm{BaP}$ dalam daging dan olahan daging adalah $5 \mu \mathrm{g} / \mathrm{kg}$ dan PAH4 (BaP, BaA, BbF, and $\mathrm{Chr}$ ) adalah $30 \mu \mathrm{g} / \mathrm{kg}$ (Komisi Eropa, 2002). Dalam sampel daging (daging sapi, ayam, dan babi) yang dipanggang (grilled/ barbecued) hingga medium-done dan di semua sampel daging dipanggang dengan metode oven-broiled, baked, roasted atau pan-fried tanpa memperhatikan tingkat kematangannya, secara umum nilainya lebih rendah dari $0,2 \mathrm{ng} / \mathrm{g}$. Demikian pula dengan HAA (Ni et al., 2008), ada perbedaan yang mencolok dalam konsentrasi $\mathrm{BaP}$ antara steak daging sapi utuh dan hamburger, jumlahnya lebih rendah terbentuk pada patties daging giling sapi .

Dalam banyak penelitian tentang makanan berbasis daging yang dimasak, fokusnya hanya di $\mathrm{BaP}$ atau $\mathrm{BaP}$ dengan sedikit PAH lainnya. Satu pengecualian adalah penelitian yang dilakukan oleh White et al. (2008) yang menyelidiki efek dari beberapa teknik memasak pada pembentukan $28 \mathrm{PAH}$, termasuk semua 16 PAH Uni Eropa, dalam makanan yang disiapkan di rumah (256 sampel) dan produk eceran yang dimasak (77 sampel). Konsentrasi $\mathrm{BaP}$ dapat diabai-kan di sebagian besar produk ritel, hanya tiga, semua burger daging sapi, mengandung konsentrasi $\mathrm{BaP}$ yang lebih tinggi $(8,4,9,8$ dan 20,4 ng/g). Mengenai praktik memasak di rumah, secara umum ada sedikit bukti pembentukan PAH percobaan grilling, frying, dan roasting. Sebaliknya, barbecuing (4 dan $7 \mathrm{~cm}$ dari sumber panas) dengan arang ditambah serpihan kayu memberi tingkat $\mathrm{BaP}$ tertinggi di setiap jenis makanan. Konsentrasi BaP maksimum ditemukan pada burger daging sapi dan sosis babi yang dipanggang dengan metode barbeceu di atas arang kayu, masingmasing 29,1 dan 30,6 ppb, dimana konsentrasi median masing-masing adalah 12,2 dan 1,9 ppb. Konsentrasi BaP maksimum pada jenis makanan panggang lainnya jauh lebih rendah daripada sosis atau burger daging sapi.

Mottier et al. (2000) menentukan 16 USEPA dalam sosis panggang yang berbeda (10 $\mathrm{cm}$ dari sumber panas) dan jumlah PAH karsinogenik (PAH8 dari EFSA) lebih tinggi pada sosis domba panggang (barbecue), 1,88 ng/g dan ketika sampel yang sama dipanggang lama/ parah, jumlah konten PAH8 adalah 13,17 ng/g. Penulis menyoroti bahwa hasil penelitian sesuai dengan temuan sebelumnya, di mana pembentukan $\mathrm{PAH}$ selama memanggang dengan arang tergantung pada kadar lemak daging, waktu memasak dan suhunya. Nilai yang lebih tinggi yang dicapai oleh White et al. (2008) dibandingkan dengan Mottier et al. (2000) mungkin karena perbedaan jarak dengan sumber panas.

EFSA (2008) menyajikan rata-rata konsentrasi $\mathrm{BaP}$ dan PAH8 daging panggang barbecue (39 sampel) masingmasing 1,92 dan 7,96 ng/g. Sampel daging panggan grill (53 sampel) rata-rata konsentrasi $\mathrm{BaP}$ dan PAH8 masing-masing 0,63 dan 3,48 ng/g. Sesuai dengan IARC, daging panggang grill secara umum diperkirakan mengandung $\mathrm{BaP}$ 10,5 ng/g (IARC, 1993). 


\section{Mitigasi Pembentukan PAH}

Mengikuti sejumlah evaluasi, IARC sampai pada kesimpulan bahwa beberapa di antara racun food-borne yang ada dalam makanan yang dimasak adalah possibly atau probably karsinogenik bagi manusia, dan baru-baru ini diklasifikasikan satu $\mathrm{PAH}$, $\mathrm{BaP}$, sebagai karsinogen bagi manusia (IARC, 2012). Meskipun PAH ada pada di tingkat ng/g dalam makanan yang dimasak, otoritas yang kompeten di sebagian besar negara-negara Barat merekomendasikan untuk meminimalkan terjadinya racun saat memasak (Jägerstad dan Skog, 2005). Oleh karena itu direkomendasikan untuk meminimalkan terjadinya HAA dalam makanan yang dikonsumsi oleh manusia.

Karena paparan ada di mana-mana, pengurangan yang efektif dari semua sumber tidak dimungkinkan. Selanjutnya, makanan panggang yang populer di rumah dan di restoran, makanan ini dapat menimbulkan risiko kesehatan karena konsentrasi karsinogen yang lebih tinggi yang ditemukan (Farhadian et al, 2011) dan pembentukan PAH.

Berbagai praktik memanggang telah menunjukkan bahwa praktik memasak tertentu di rumah dapat menyebabkannya tingkat $\mathrm{PAH}$ yang lebih tinggi dibandingkan dengan konsentrasi PAH dalam makanan yang disiapkan dengan praktik yang tepat (EFSA, 2008). Pembentukan PAH selama memasak makanan dapat dikurangi jika lemak dari daging yang berlebih dikurangi dan daging dimasak pada suhu yang lebih rendah, atau waktu yang singkat, atau memilih jarak yang sesuai dengan bara arang untuk menghindari kontak dengan sumber panas (Lijinsky dan Ross, 1967). Untuk teknik meminimalkan pembentukan PAH yang menghindari pirolisis lemak yang jatuh ke dalam api, adalah pemanggangan yang lebih disukai, yaitu pemanggang listrik dengan sumber panas di atas makanan, atau pemanggang lain yang sesuai yang didesain vertikal (Saint-Aubert et al., 1992) atau dengan panci berisi air di bawahnya resistensi listrik (Lintas et al., 1979). Panggangan arang harus dilakukan di atas bara dan hindari kontak langsung daging dengan api atau hindari pemanggangan pada suhu tinggi (Chen dan Lin, 1997).

Studi terbaru telah muncul dengan strategi mitigasi baru mengenai pembentukan PAH dalam makanan yang dipanggang. Farhadian et al.(2011) menunjukkan bahwa pemanasan awal yang diterapkan (steam dan microwave) dan perlakuan pembungkusan (aluminium dan daun pisang) pada sampel (daging sapi dan ayam) dengan kuat mengurangi tingkat PAH dalam daging panggang arang. Janoszka (2011) mengamati bahwa bawang bombay (30/100 g daging) menyebabkan penurunan rata-rata $60 \%$ dari total konten PAH dalam daging babi goreng dan bawang putih (15/100 g daging) menurunkan konsentrasi 54\%. Penulis membenarkan yang diamati karena efek dengan kehadiran banyak senyawa dengan aktivitas antioksidan yang dapat mengais / menyergap radikal bebas yang terlibat dalam pembentukan $\mathrm{PAH}$.

\section{SIMPULAN}

HAA dan PAH adalah mutagen kuat yang terbentuk dalam produk daging yang dipanaskan. Pembentukan mereka sangat tergantung pada berbagai faktor seperti metode pemasakan, waktu pemasakan, suhu pemasakan, jenis daging, kandungan lemak, kadar air, pH dan kandungan kreatinin daging. Banyak penelitian menyimpulkan bahwa HAA dan PAH menyebabkan kanker pada manusia dan hewan. Setidaknya ada 4 
cara yang bisa kita pilih untuk dengan sumber panas yang didesain di atas meminimalkan kandungan HAA pada daging atau vertikal; menerapkan olahan daging panggang/ bakar/ goreng, pemanasan awal (steam dan microwave) yakni: memilih gula yang tepat untuk sebelum pemanggangan; praperlakuan marinasi; penambahan antioksidan sintetis; pembungkusan daging (aluminium dan daun penambahan antioksidan alami; dan pisang); dan marinasi daging dengan bumbu praperlakuan menggunakan microwave. kaya antioksidan. Para widyaiswara PAH dapat dikurangi dengan mengurangi diharapkan untuk bisa menyebarluaskan dan lemak yang berlebih; memasak daging pada suhu yang lebih rendah atau waktu yang singkat; menghindari kontak dengan bara arang kayu saat memanggang; menggunakan alternatif pemanggang listrik menerapkan informasi cara praktis untuk meminimalkan kandungan karsinogen HAA dan PAH pada olahan daging panggang/ bakar/ goreng melalui pelatihan-pelatihan teknis yang diampunya.

\section{DAFTAR PUSTAKA}

Aaslyng, M. D., Duedahl-Olesen, L., Jensen, K., \& Meinert, L. (2013). Content of heterocyclic amines and polycyclic aromatic hydrocarbons in pork, beef and chicken barbecued at home by Danish consumers. Meat Science, 93(1), 85-91.

Archer, C. L., Morse, P., Jones, R. F., Shirai, T., Haas, G. P., \& Wang, C. Y. (2000). Carcinogenicity of the N-hydroxy derivative of 2-amino-1-methyl-6-phenylimidazo [4, 5-b] pyridine, 2-amino-3, 8-dimethyl-imidazo [4, 5-f] quinoxaline and 3, 2'dimethyl-4-aminobiphenyl in the rat. Cancer letters, 155(1), 55-60.

Chen, B.H., Lin, Y.S. (1997). Formation of polycyclic aromatic hydrocarbons during processing of duck meat. J. Agric. Food Chem. 45, 1394-1403.

Cheng, K. W., Wong, C. C., Chao, J., Lo, C., Chen, F., Chu, I. K., ... \& Wang, M. (2009). Inhibition of mutagenic PhIP formation by epigallocatechin gallate via scavenging of phenylacetaldehyde. Molecular nutrition \& food research, 53(6), 716-725.

Cheng, K.W., Chen, F., Wang, M.F. (2006). Heterocyclic amines: Chemistry and health. Mol. Nutr. Food Res. 50, 1150-1170.

Commoner, B., Vithayathil, A. J., Dolara, P., Nair, S., Madyastha, P., \& Cuca, G. C. (1978). Formation of mutagens in beef and beef extract during cooking. Science, 201(4359), 913-916.

EFSA (European Food Safety Agency). (2008). Scientific opinion of the panel on contaminants in the food chain on a request from the European Commission on polycyclic aromatic hydrocarbons in Food. EFSA Journal 724, 1-114.Farhadian et al, 2011

Esumi, H., Ohgaki, H., Kohzen, E., Takayama, S., \& Sugimura, T. (1989). Induction of Lymphoma in CDF1 Mice by the Food Mutagen, 2-Amino-1-methyl-6phenylimidazo [4, 5-b] pyridine. Japanese journal of cancer research, 80(12), 11761178 .

Farhadian, A., Jinap, S., Abas, F., Sakar, Z.I. (2010). Determination of polycyclic aromatic hydrocarbons in grilled meat. Food Control 21, 606-610. 
Farhadian, A., Jinap, S., Hanifah, H.N., Zaidul, I.S. (2011). Effects of meat preheating and wrapping on the levels of polycyclic aromatic hydrocarbons in charcoal-grilled meat. Food Chem. 124, 141-146.

Felton J, Knize M (1990) Heterocyclic-amine mutagens/carcinogens in foods. In: Chemical carcinogenesis and mutagenesis I. Springer, Berlin, pp 471-502.

Felton, J. S., Fultz, E., Dolbeare, F. A., \& Knize, M. G. (2000). Reduction of heterocyclic aromatic amine mutagens/carcinogens in fried beef patties by microwave pretreatment. Biology and Biotechnology Research Program, L-452, Lawrence Livermore National Laboratory, P.O. Box 808, Livermore, CA 94551-9900.

Ferrarese, E., Andreottola, G., Oprea, I.A. (2008). Remediation of PAH-contaminated sediments by chemical oxidation. J. Hazard. Mater. 158, 128-39.

Hasnol, N. D. S., Jinap, S., \& Sanny, M. (2014). Effect of different types of sugars in a marinating formulation on the formation of heterocyclic amines in grilled chicken. Food chemistry, 145, 514-521.

IARC (International Agency for Research on Cancer). (1993). Some naturally occuring substances: Food items and constituents, heterocyclic aromatic amines and mycotoxins. In: IARC Monogr. Eval. Carcinog. Risks Hum. IARC Publications, Lion, Vol. 56, pp. 163-242.

IARC (International Agency for Research on Cancer). (2010). Some non-heterocyclic polycyclic aromatic hydrocarbons and some related exposures. In: IARC Monogr. Eval. Carcinog. Risks Hum. IARC Publications, Lion, Vol. 92, pp. 1-845.

IARC (International Agency for Research on Cancer). (2012). A Review of Human Carcinogens: Chemical Agents and Related Occupations. In: IARC Monogr. Eval. Carcinog. Risks Hum. Vol. 100F. http://monographs.iarc.fr/ENG/Monographs/vol100F/mono100F-14.pdf.

IPCS (International Programme on Chemical Safety). (1998). Selected Non-heterocyclic Polycyclic Aromatic Hydrocarbons. Environmental Health Criteria 202. International Programme on Chemical Safety, World Health Organization, Geneva.

Ito, N., Hasegawa, R., Sano, M., Tamano, S., Esumi, H., Takayama, S., \& Sugimura, T. (1991). A new colon and mammary carcinogen in cooked food, 2-amino-1-methyl-6phenylimidazo [4, 5-b] pyridine (PhIP). Carcinogenesis, 12(8), 1503-1506.

Jägerstad, M., Skog K. (2005). Genotoxicity of heat-processed foods. Mutat. Res. 574, $156-172$.

Jägerstad, M., Skog, K., Arvidsson, P., Solyakov, A. (1998). Chemistry, formation and occurrence of genotoxic heterocyclic amines identified in model systems and cooked foods. Z. LebensmUnters Forsch. A 207, 419-427.

Jägerstad, M., Skog, K., Grivas, S., \& Olsson, K. (1991). Formation of heterocyclic amines using model systems. Mutation Research/Genetic Toxicology, 259(3-4), 219-233.

Janoszka, B. (2011). HPLC-fluorescence analysis of polycyclic aromatic hydrocarbons (PAHs) in pork meat and its gravy fried without additives and in the presence of onion and garlic. Food Chem. 126, 1344-1353.

JEFCA (Joint Expert Committee on Food Additives). (2005). Joint FAO/WHO expert committee on food additives. Sixty-fourth meeting, Rome, 8e17 Mei 2020. Summary 
and

conclusions.

Available

on: http://www.who.int/ipcs/food/jecfa/summaries/summary_report_64_final.pdf

Kasai, H., Nishimura, S., Wakabayashi, K., Nagao, M., \& Sugimura, T. (1980a). Chemical synthesis of 2-amino-3-methylimidazo-[4, 5-f] quinoline (IQ), a potent mutagen isolated from broiled fish. Proceedings of the Japan Academy, Series B, 56(6), 382384.

Kasai, H., Yamaizumi, Z., Shiomi, T., Yokoyama, S., Miyazawa, T., Wakabayashi, K., ... \& Nishimura, S. (1981). Structure of a potent mutagen isolated from fried beef. Chemistry Letters, 10(4), 485-488.

Kasai, H., Yamaizumi, Z., Wakabayashi, K., Nagao, M., Sugimura, T., Yokoyama, S., ... \& NISHIMURA, S. (1980b). Potent novel mutagens produced by broiling fish under normal conditions. Proceedings of the Japan Academy, Series B, 56(5), 278-283.

Kazerouni, N., Sinha, R., Hsu, C. H., Greenberg, A., Rothman, N., 2001. Analysis of 200 food items for benzo $[a]$ pyrene and estimation of its intake in an epidemiologic study. Food Chem. Toxicol. 39, 423-436.

Komisi Eropa (European Commission). (2002). Opinion of the Scientific Committee on Food on the risks to human health of Polycyclic Aromatic Hydrocarbons in food. Available on: http://ec.europa.eu/food/fs/sc/scf/out153_en.pdf.

Komisi Eropa (European Commission). (2005). Commission regulation no. 208/2005 of 4 February 2005 amending regulation (EC) no. 466/2001 as regards polycyclic aromatic hydrocarbons, Off. J. Eur. Union L34 (2005) 3.

Kosuge, T., Tsuji, K., Wakabayashi, K., Okamoto, T., Shudo, K., Iitaka, Y., ... \& Yahagi, T. (1978). Isolation and structure studies of mutagenic principles in amino acid pyrolysates. Chemical and Pharmaceutical Bulletin, 26(2), 611-619.

Lan, C.M., Chen B.H. (20020. Effects of soy sauce and sugar on the formation of heterocyclic amines in marinated foods. Food Chem. Toxicol. 40, 989-1000.

Lijinsky, W., Ross, A.E. (1967). Production of carcinogenic polynuclear hydrocarbons in the cooking of food. Food Cosmet. Toxicol. 5, 343-347.

Lintas, C., de Matthaeis, M.C., Merli, F. (1979). Determination of benzo[a]pyrene in smoked, cooked and toasted food products. Food Cosmet. Toxicol. 17, 325-328.

Luch, A., Baird, W.M. (2010). Carcinogenic Polycyclic Aromatic Hydrocarbons. In: McQueen, C.A. (Ed.), Comprehensive Toxicology. Elsevier Ltd., Vol.14, pp. 85123.

Martorell, I., Perello, G., Marti-Cid, R., Castell, V., Llobet, J.M., Domingo, J.L. (2010). Polycyclic aromatic hydrocarbons (PAH) in foods and estimated PAH intake by the population of Catalonia, Spain: Temporal trend. Environ. Int. 36, 424-432.

Milić BL, Djilas SM, С̆ anadanović-Brunet JM (1993) Synthesis of some heterocyclic aminoimidazoazarenes. Food Chem 46(3):273-276

Mottier, P., Parisod, V. and Turesky, R.J. (2000). Quantitative determination of polycyclic aromatic hydrocarbons in barbecued meat sausages by gas chromatography coupled to mass spectrometry. J. Agric. Food Chem. 48, 1160-1166.

Nagao, M., Honda, M., Seino, Y., Yahagi, T., \& Sugimura, T. (1977a). Mutagenicities of smoke condensates and the charred surface of fish and meat. Cancer letters, 2(4-5), 221-226. 
Nagao, M., Yahagi, T., Seino, Y., Sugimura, T., \& Ito, N. (1977b). Mutagenicities of quinoline and its derivatives. Mutation Research/Fundamental and Molecular Mechanisms of Mutagenesis, 42, 335-341.

Ni, W., McNaughton, L., LeMaster, D.M., Sinha, R., Turesky, R.J. (2008). Quantitation of 13 heterocyclic aromatic amines in cooked beef, pork, and chicken by liquid chromatographyelectrospray ionization/tandem mass spectrometry. J. Ag

Ohgaki, H., Takayama, S., \& Sugimura, T. (1991). Carcinogenicities of heterocyclic amines in cooked food. Mutation Research/Genetic Toxicology, 259(3-4), 399-410.

Pais P et al (1999) Formation of mutagenic/carcinogenic heterocyclic amines in dry-heated model systems, meats, and meat drippings. J Agric Food Chem 47(3):1098-1108

Park, J.H., Penning, T.M. (2009). Polyaromatic Hydrocarbons. In: Stadler, R.H., Lineback, D.R., Process-Induced Food Toxicants: Occurrence, Formation, Mitigation, and Health Risks,Copyright. John Wiley \& Sons, Inc., New Jersey, pp. 243-282.

Persson, E., Sjöholm, I., Skog, K. (2003). Effect of high water-holding capacity on the formation of heterocyclic amines in fried beefburgers. J. Agric. Food Chem. 51, 4472-4477.

Plaza-Bolaños, P., Frenich, A.G., Vidal, J.L. (2010). Polycyclic aromatic hydrocarbons in food and beverages. Analytical methods and trends. J. Chromatogr. A 121, 63036326.

Ramesh, A., Walker, S.A., Hood, D.B., Guillén, M.D., Schneider, K. and Weyand, E.H. (2004). Bioavailability and risk assessment of orally ingested polycyclic aromatic hydrocarbons. Int. J. Toxicol. 23, 331-333.

Saint-Aubert, B., Cooper, J.F., Astre, C., Spiliotis, J., Joyeux, H. (1992). Evaluation of the induction of polycyclic aromatic hydrocarbons by cooking on two geometrically different types of barbecue. J. Food Compos. Anal. 5, 257-263.

Shan, L., Yu, M., Schut, H. A., \& Snyderwine, E. G. (2004). Susceptibility of rats to mammary gland carcinogenesis by the food-derived carcinogen 2-amino-1-methyl-6phenylimidazo [4, 5-b] pyridine (PhIP) varies with age and is associated with the induction of differential gene expression. The American journal of pathology, 165(1), 191-202.

Shin HS, Strasburg GM, Gray JI (2002) A model system study of the inhibition of heterocyclic aromatic amine formation by organosulfur compounds. J Agric Food Chem 50(26):7684-7690

Šimko, P. (2002). Determination of polycyclic aromatic hydrocarbons in smoked meat products and smoke flavouring food additives. J. Chromatogr. B 770,

Sinha, R., Rothman, N., Brown, E.D., Salmon, C.P., Knize, M.G., Swanson, C.A., Rossi, S.C.,

Mark, S.D., Levander, O.A., Felton, J.S. (1995). High concentrations of the carcinogen 2- amino-1-methyl- 6-phenylimidazo-[4,5-b]pyridine (PhIP) occur in chicken but are dependent on the cooking method. Cancer Res. 55, 4516-4519.

Skog, K., Augustsson, K., Steineck, G., Stenberg, M., \& Jägerstad, M. (1997). Polar and non-polar heterocyclic amines in cooked fish and meat products and their corresponding pan residues. Food and Chemical Toxicology, 35(6), 555-565.

Skog K, Solyakov A, Jagerstad M (2000) Effects of heating conditions and additives on the formation of heterocyclic amines with reference to amino-carbolines in a meat juice model system. Food Chem 68(3):299-308 
Skog K, Solyakov A, Jägerstad M (2000) Effects of heating conditions and additives on the formation of heterocyclic amines with reference to amino-carbolines in a meat juice model system. Food Chem 68(3):299-308.

Skog, K. I., Johansson, M. A. E., \& Jägerstad, M. I. (1998). Carcinogenic heterocyclic amines in model systems and cooked foods: a review on formation, occurrence and intake. Food and Chemical Toxicology, 36(9-10), 879-896.

Skog, K., Johansson, M., Jägerstad, M. (1998). Carcinogenic heterocyclic amines in model systems and cooked foods: A review on formation, occurrence and intake. Food Chem. Toxicol. 36, 879-896.

Sugimura, T. (1986). Studies on environmental chemical carcinogenesis in Japan. Science, 312-318.

Sugimura, T. (1992). Multistep carcinogenesis: a 1992 perspective. Science, 258(5082), 603-607.

Sugimura, T. (1997a). Overview of carcinogenic heterocyclic amines. Mutation Research, 376(1-2), 211-219.

Sugimura, T., Yokoi, H., Sato, N., Akagi, T., Kimura, T., Iemura, M., ... \& Kato, H. (1997b). Interventional treatment for children with severe coronary artery stenosis with calcification after long-term Kawasaki disease. Circulation, 96(11), 3928-3933.

Takahashi, M., Toyoda, K., Aze, Y., Furuta, K., Mitsumori, K., \& Hayashi, Y. (1993). The Rat Urinary Bladder as a New Target of Heterocyclic Amine Carcinogenicity: Tumor Induction by 3-Amino-1-methyl-5H-pyrido [4, 3- $\beta$ ] indole Acetate. Japanese journal of cancer research, 84(8), 852-858.

Tamano, S., Hasegawa, R., Hagiwara, A., Nagao, M., Sugimura, T., \& Ito, N. (1994). Carcinogenicity of a mutagenic compound from food, 2-amino-3-methyl-9 H-pyrido [2, 3-b] indole (MeA $\alpha \mathrm{C})$, in male F344 rats. Carcinogenesis, 15(9), 2009-2015.

Tang, D., Liu, J. J., Rundle, A., Neslund-Dudas, C., Savera, A. T., Bock, C. H., ... \& Rybicki, B. A. (2007). Grilled meat consumption and PhIP-DNA adducts in prostate carcinogenesis. Cancer Epidemiology and Prevention Biomarkers, 16(4), 803-808.

Tsuda, M., Negishi, C., Makino, R., Sato, S., Yamaizumi, Z., Hirayama, T., \& Sugimura, T. (1985). Use of nitrite and hypochlorite treatments in determination of the contributions of IQ-type and non-IQ-type heterocyclic amines to the mutagenicities in crude pyrolyzed materials. Mutation Research/Environmental Mutagenesis and Related Subjects, 147(6), 335-341.

Wakabayashi, K., Nagao, M., Esumi, H., \& Sugimura, T. (1992). Food-derived mutagens and carcinogens. Cancer Research, 52(7 Supplement), 2092s-2098s.

Wang, Q., Bi, Y., Chen, F., \& Cheng, K. W. (2019). Heterocyclic Amines in Foods: Analytical Methods, Formation Mechanism, and Mitigation Strategies. In Chemical Hazards in Thermally-Processed Foods (pp. 107-119). Springer, Singapore.

Weisburger JH (2005) Specific maillard reactions yield powerful mutagens and carcinogens. In: Labuza TP et al (eds) Maillard reactions in chemistry, food and health. Woodhead Publishing, Cambridge, pp 335-340

Wenzl, T., Simon, R., Anklam, E., Kleiner, J. (2006). Analytical methods for polycyclic aromatic hydrocarbons (PAHs) in food and the environment needed for new food legislation in the European Union. Trend. Anal. Chem. 25, 716-725. 
White, S., Fernandes, A. and Rose, M. (2008). Investigation of the formation of PAHs in foods prepared in the home and from catering outlets to determine the effects of frying, grilling, barbecuing, toasting and roasting. FD 06/13. Food Standard Agency (FSA)/Central Science Laboratory (CSL).

Widmark, E. M. P. (1939). Presence of cancer-producing substances in roasted food. Nature, 143(3632), 984-984.

Yahagi, T., Nagao, M., Seino, Y., Matsushima, T., Sugimura, T., \& Okada, M. (1977). Mutagenicities of N-nitrosamines on Salmonella. Mutation Research/Fundamental and Molecular Mechanisms of Mutagenesis, 48(2), 121-129.

Yamamoto, M., Yamada, T., \& Tanimura, A. (1980). Volatile nitrosamines in human blood before and after ingestion of a meal containing high concentrations of nitrate and secondary amines. Food and cosmetics toxicology, 18(3), 297-299.

Yoshida, D., Matsumoto, T., Yoshimura, R., \& Matsuzaki, T. (1978). Mutagenicity of amino- $\alpha$-carbolines in pyrolysis products of soybean globulin. Biochemical and biophysical research communications, 83(3), 915-920.

Zhang Q, Li G, Xiao X (2015) Acrylamide-modified graphene for online micro-solidphase extraction coupled to high-performance liquid chromatography for sensitive analysis of heterocyclic amines in food samples. Talanta 131:127-135

Zhu, X., Ni, X., Waigi, M. G., Liu, J., Sun, K., \& Gao, Y. (2016). Biodegradation of mixed PAHs by PAH-degrading endophytic bacteria. International journal of environmental research and public health, 13(8), 805 . 